\title{
Characteristics of Sickle Cell Trait Policies and Procedures at NCAA Division II Institutions
}

ISSN: 2577-1914

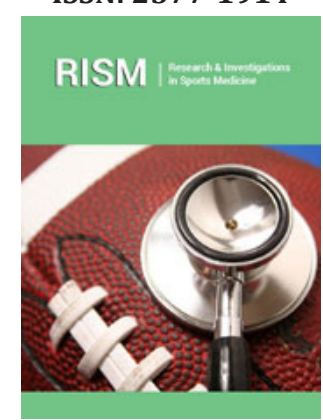

*Corresponding author: S Andrew C, University of Texas at Tyler, Texas, USA

Submission: 鰃January 30, 2020

Published: 眥February 26, 2020

Volume 6 - Issue 1

How to cite this article: $S$ Andrew $C^{*}$, Brandon W, Diana G, Catherine F, Kristen S. Characteristics of Sickle Cell Trait Policies and Procedures at NCAA Division II Institutions. Res Inves Sports Med, 6(1): RISM.000630.2020

DOI: $10.31031 /$ RISM.2020.06.000630

Copyright@ S Andrew C, This article is distributed under the terms of the Creative Commons Attribution 4.0 International License, which permits unrestricted use and redistribution provided that the original author and source are credited.

\author{
S Andrew C*, Brandon W, Diana G, Catherine F and Kristen S \\ University of Texas at Tyler, USA \\ Grand Canyon University, USA \\ Christus Trinity Mother Frances, USA
}

\begin{abstract}
In 2010, the National Collegiate Athletic Association (NCAA) introduced a proposal addressing sickle cell trait (SCT) screening. This new proposal policy required all NCAA Division I student-athletes beginning their initial year of enrollment provide their institution with accurate information regarding their SCT status. Following the NCAA Division II creating this requirement, the NCAA Division II adopted the same requirement. In addition to these screening requirements, the National Athletic Trainers' Association (NATA) released a statement recommending institutions utilized education on SCT as a method of preventing SCT related injury. To the author's knowledge, there does not appear to be a study conducted in recent years to assess how many institutions are following the NCAA and NATA's recommendations on SCT screening. Therefore, the purpose of this study is to describe the basic characteristics of SCT policies and procedures at NCAA Division II institutions. 73 NCAA Division II head athletic trainers participated in this study. Participants were sent an electronic survey via email that assessed availability sickle cell trait testing, availability of sickle cell trait waivers, and policy and procedure revision processes. Data was downloaded and analyzed using a commercially available statistics package (SPSS Version 26, IBM, Armonk, NY). The majority of head athletic trainers reported that their institution required SCT testing for their student-athletes $(n=40,54.8 \%) .62$ institutions reported offering SCT testing to their student-athletes either at the institution's or the student-athlete's expense. However, only a slight majority of institutions provided their student-athlete population with yearly education on SCT $(n=41,56.2 \%)$. On average, institutions and team physicians reviewed SCT policies and procedures on an annual basis. 19.2\% ( $n=14)$ of institutions had not reviewed their policy in the past two years, and $15.1 \%(n=11)$ of institutions did not have polices that had been reviewed by their team physician in the past two years. While the majority of responding institutions appeared to be at least minimally compliant with SCT screening procedures, athletic training staff and institutions should be encouraged to conduct annual reviews of the SCT screening policies and procedures. Institutions should consider implementing annual sickle cell trait education for student-athletes
\end{abstract}

\section{Introduction}

Sickle cell trait (SCT) is a condition that manifests in individuals who inherit one normal beta hemoglobin allele, and one sickle beta hemoglobin allele. SCT is a separate condition from sickle cell disease in which individuals inherit two sickle hemoglobin alleles [1]. In the United States, these conditions are detected during newborn screening, but parents are not typically informed about SCT status unless the information is requested [2]. In general, SCT is more common among people with heritage Sub-Saharan Africa, the Mediterranean region, the Arabian Peninsula, the Caribbean, and South and Central America [3]. In 2015, it was reported that 3 million Americans carry SCT, including 8\% of blacks, .5\% of Hispanics, and $.2 \%$ of whites [4].

In 2010, National Collegiate Athletic Association (NCAA) introduced a proposal addressing SCT screening [3]. This policy required all NCAA Division I student-athletes beginning their eligibility to provide their institution with accurate information regarding their SCT status. Later, this policy was also adopted by the NCAA Division II. Student-athletes could provide this information through either undergoing a sickle cell solubility test, producing proof of previous SCT testing, or signing a waiver that allowed the student-athlete to opt out of screening while indemnifying the institution [3]. To date, SCT is the only condition specifically tested for among student-athletes in the NCAA [3].

Within athletic training, there has been a growing emphasis on SCT screening and education [3]. In 2007, the National Athletic Trainers' Association (NATA) released a consensus statement on managing physically active patients with SCT [5]. One of the NATA's 
primary recommendations for preventing SCT injuries and death was to ensure that all student-athletes, coaches, and medical staff received regular education on SCT [5]. Previous studies have examined the experiences of athletic trainers and team physicians when implementing the NCAA SCT policy $[3,6]$. However, the most recent study found by the authors that examined these policies at the NCAA Division II level took place nine years prior to the initiation of this study. Therefore, the purpose of this study was to gather information about the characteristics of sickle cell trait policies and procedures at NCAA Division II institutions.

\section{Methods}

\section{Design}

This study was conducted using a cross sectional design utilizing an internet-based survey for data collection.

\section{Participants}

Participants were recruited for this study by collecting email address for head athletic trainers of NCAA Division II institutions by using the staff directories on the targeted institutions' websites. A total of 288 NCAA Division II head athletic trainers were emailed. Ten emails were sent back to the authors due to either the athletic trainer no longer being employed at the institution $(n=3)$ or that the email address no longer existed $(n=7) .73$ participants (age $=$ $42.5 \pm 9.8$ years, years of certified experience $=19.5 \pm 9.3$, years of head athletic trainer experience $=13.1 \pm 10.7$ ) opened the survey link and completed the instrument (access and completion rates = $26.3 \%$ ). All participants were informed of the survey's purpose as part of the beginning of the survey, at which point informed consent was obtained.

\section{Data collection}

An email message was sent to all prospective participants inviting them to participate in a survey via a hyperlink from a webbased server (Qualtrics Inc., Provo, UT) from January to February 2020. The inviting message contained information about the investigators, the purpose of the study, the nature of the survey, and assurances that the participants could opt to not complete the survey at any time. A follow-up email as sent a week after the initial email and left open for a week after prior to the survey being closed for statistical analysis.

\section{Instrument}

Following the informed consent and demographics section, the instrument contained items related to years of experience as a certified athletic trainer and as a head athletic trainer, as well as the SCT screening and education requirements for studentathletes at the participant's institution. Participants were also asked to answer a question about whether or not SCT and sickle cell disease were different conditions. The survey consisted of 16 total questions. These questions included: one question regarding consent to participate in the study, two multiple choice and four fill in the blank questions regarding demographic information, six multiple choice, and three fill in the blank questions regarding the implementation and review of SCT policies, and one multiple choice question on whether or not SCT and sickle cell disease were different conditions.

\section{Statistical analysis}

Information from participant responses was downloaded and analyzed using a commercially available statistics package (SPSS Version 26, IBM, Armonk, NY). Of the 278 NCAA Division II head athletic trainers who received the invitation to participate in the survey, 73 completed responses were included in the data analysis. Measures of central tendency (means, standard deviations, frequencies) were calculated where appropriate. Results were then compiled and compared to NCAA and NATA recommendations.

\section{Results}

\section{Sickle cell trait policies and procedures}

The majority of responding NCAA Division II institutions currently require SCT testing $(n=40,54.8 \%)$. Additionally, the majority of institutions also provided opportunities for SCT testing in some form $(n=62,85 \%)$. However, only a slight majority provided SCT education to their student-athletes $(n=41,56.2 \%)$. Table 1 provides a breakdown of the questions that gathered information on institutions' SCT policies and procedures.

Table 1: Responses for questions on implementation and review of sickle cell trait policies and procedures.

\begin{tabular}{|c|c|}
\hline Question & Most Common Responses (\%) \\
\hline Does your institution currently require SCT testing? & $\begin{array}{c}\text { Yes, } 40 \text { (54.8\%) } \\
\text { No, 33 (45.2\%) }\end{array}$ \\
\hline $\begin{array}{c}\text { Does your institution provide opportunities for student-athletes to undergo SCT test- } \\
\text { ing? }\end{array}$ & $\begin{array}{c}\text { Yes, at the individual's expense, } 41(56.2 \%) \\
\text { Yes, at the institution's expense, 21 (28.8\%) }\end{array}$ \\
\hline Does your institution require student-athletes to sign a waiver if they decline SCT \\
testing?
\end{tabular}




\begin{tabular}{|l|c|}
\hline $\begin{array}{l}\text { What would you say is the likelihood that there are student-athletes at your institution } \\
\text { who have SCT, but do not realize it? }\end{array}$ & $\begin{array}{c}\text { Very Unlikely, 18 (24.7\%) } \\
\text { Somewhat Likely, 18 (24.7\%) } \\
\text { Unlikely, 15 (20.6\%) }\end{array}$ \\
\hline $\begin{array}{c}\text { For which sports does your institution have onsite emergency oxygen during competi- } \\
\text { tions? }\end{array}$ & None, $357.9 \%)$ \\
& Basketball, 25 (34.2\%) \\
& Football 21 (28.8\%) \\
\hline
\end{tabular}

\section{Sickle cell trait policy and procedures revision practices}

On average, institutions and team physicians reviewed sickle cell trait policies and procedures on a yearly basis. $19.2 \%(n=14)$ of institutions had not reviewed their sickle cell trait policies within the past two years. $15.1 \%(n=11)$ of institutions did not have sickle cell trait policies and procedures that had been reviewed by their team physician in the past two years. Furthermore, $4.1 \%(n=3)$ of institutions reported either never reviewing their policy or being unsure of the last time it was reviewed, and 15.1\% (n=11) of institutions reported never having their policy reviewed by their team physician. When answering a question on whether or not SCT and sickle cell disease were the same condition, 4 (5.5\%) stated the two conditions were the same.

\section{Discussion}

The purpose of this study was to describe the characteristics of SCT policies and procedures at NCAA Division II institutions. A secondary purpose was to describe the frequency of revisions to institutional SCT policies and procedures. Our findings indicate that the majority of NCAA Division II institutions surveyed required their student-athletes to undergo SCT screening ( $n=40,54.8 \%)$ and provide access to SCT screening either at the institution or the individuals' expense ( $41=$ at the individual's expense, $56.2 \%$, $21=$ at the institution's expense, $28.8 \%$ ). However, only $56.2 \%$ of institutions $(n=41)$ required student-athletes to undergo yearly SCT education. Additionally, some institutions reported using SCT policies and procedures that had not been reviewed by the institution or the team physician within the past two years. This suggests that while the majority of schools surveyed are at least minimally compliant with NCAA requirements, there may be opportunities for improvement per NATA recommendations [5].

A previous study conducted in 2011 suggested that SCT screening of all student-athletes at NCAA Division II institutions was relatively uncommon [6]. The findings of the current study suggest that more institutions may have begun screening all their student-athletes for SCT during this time. Given that both studies were anonymous, it is difficult to determine if any institutions that had previously been screening all of their student-athletes for SCT have ceased this practice.

These findings may suggest a need for further reform in terms of how SCT policies and procedures are implemented. As previously stated, most institutions are in fact at least minimally compliant with NCAA requirements for SCT screening. However, in order to better utilized the recommendations, set forth by the NATA, institutions should consider re-evaluating their SCT education and SCT policy and procedures revision practices. Given that 4 participants (5.5\%) stated that SCT and sickle cell disease were the same condition, there may also be a need for an increase in continuing education on SCT to ensure that all athletic trainers understand the basic differences between these two conditions.

A possible limitation of this study was the low response rate for the survey. This is a similar limitation that other survey-based studies on athletic trainers have encountered and may affect the generalizability of the results when looking to analyze across the profession [7]. However, the $26.3 \%$ was higher than some surveybased studies on athletic trainers in the past [7]. There is a need for additional research on policies and procedures to address SCT and other potentially harmful or fatal conditions. To date, SCT is the only condition that has specific guidelines from the NCAA, in spite of the fact that there are other potentially life altering or threatening conditions that student-athletes may be participating in sport with [3]. Future research could also be conducted on the perceived and actual knowledge of general medical conditions among currently practicing athletic trainers.

\section{Conclusion}

In conclusion, the majority of NCAA Division II institutions appear to be at least minimally compliant with NCAA SCT regulations. However, the results of this study also suggest that there could be improvements made with regards to SCT education and SCT policy and procedures revision practices. Given that SCT is a condition of particular concern with regard to sudden death in athletics, it is important for institutions to make sure that they are practicing the best possible policies and procedures in order to mitigate the risk to student-athletes who have, or potentially have SCT.

\section{References}

1. Tsaras G, Owusu-Ansah A, Bosteng FO, Amoateng-Adjepong Y (2009) Complications associated with sickle cell trait: A brief narrative review. Am J Med 122(6): 507-512.

2. Ojodu J, Hulihan M, Pope SN, Grant AM (2010) Incidence of sickle cell trait-United States, 2010. Morbidity and Mortality Weekly Report 63(49): 1155.

3. McDonald MA, Creary MS, Powell J, Daley LA, Baker C, Royal CM (2017) Perspectives and practices of athletic trainers and team physicians implementing the 2010 NCAA sickle cell trait screening policy. J Genet Couns 26(6): 1292-1300.

4. The Sickle Cell Disease Association of America (2015) Sickle Cell Disease Global.

5. National Athletic Trainers' Association (2007) Consensus statement: Sickle cell trait and the athlete. 
6. Jung AP, Selmon PB, Lett JL, Petrella JK (2011) Survey of sickle cell trait screening in NCAA and NAIA institutions. The Physician and Sports Medicine 39(1): 158-165.
7. Yang CW, Yen ZS, McGowan JE, Chen HC, Chiang WC, et al (2012) A systematic review of retention of adult advanced life support knowledge and skills in heathcare providers. Resuscitation 83(9): 1055-1060.

For possible submissions Click below: 